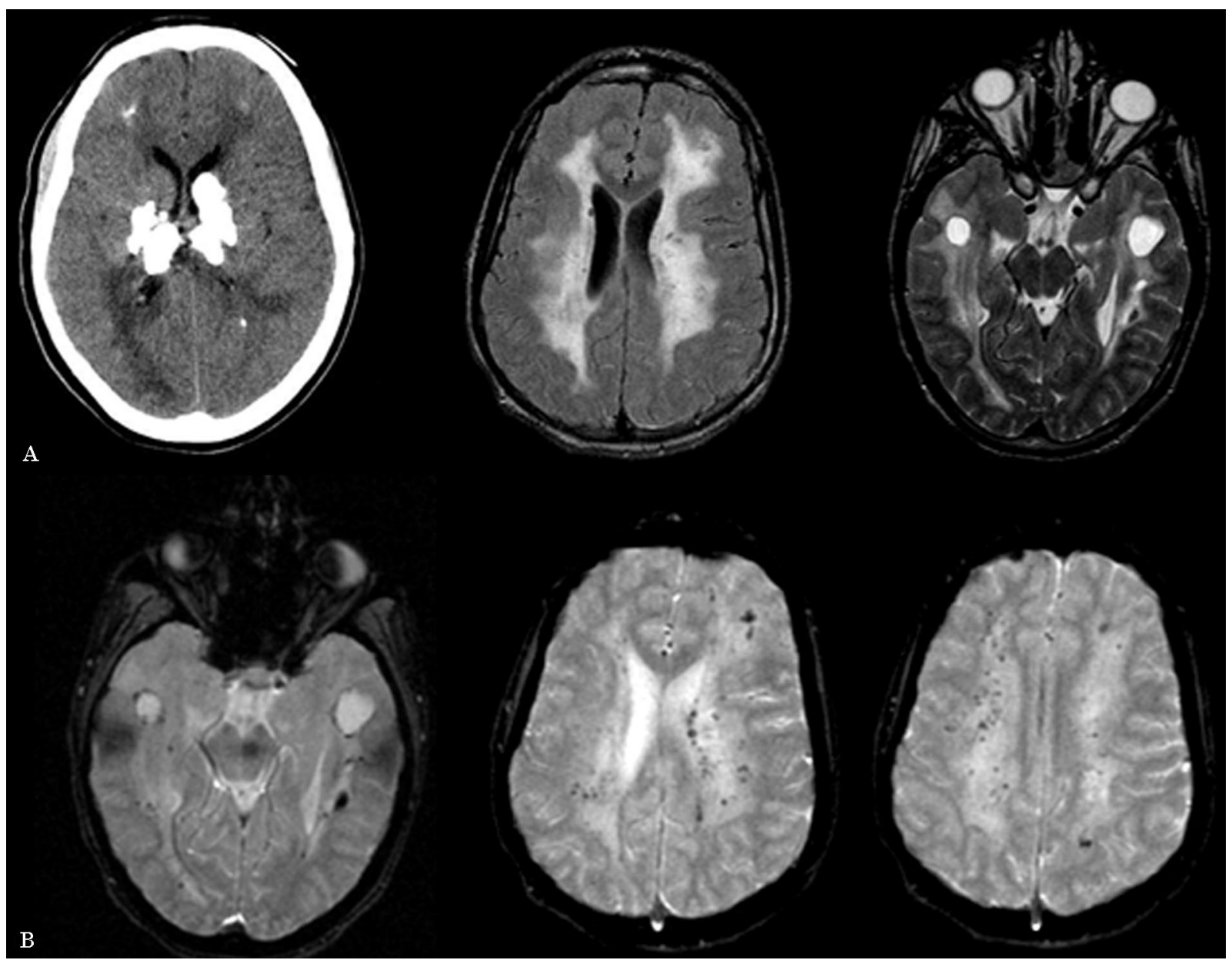

Figure. (A) CT and MRI display calcification of the dentate nuclei, thalamus, basal ganglia, subcortical white matter, leukoencephalopathy, and cysts. (B) Gradient echo images show countless tiny, deep, hypointense, round lesions in the supratentorial white matter, in the periventricular region, and around the cystic lesions in the temporal lobes.

\section{Leukoencephalopathy with cerebral calcifications and cysts}

Christiana Brenner, MD; Maria C. Del Negro, MD;

Eliana M.V. Borigato, MD, PhD; and Robson V. Miranda, MD, Brasília, Brazil

The patient is a 20-year-old woman with an unremarkable family history who began to have focal seizures at age 1 month.

Disclosure: The authors report no conflicts of interest.

Address correspondence and reprint requests to Dr. Christiana Brenner, SQN 112 Bloco "A" Apt 602, Brasilia DF Brazil, 70762010; e-mail: c.brenner@uol.com.br
Progressive ataxia, generalized dystonia, spasticity, dysarthria, and cognitive decline started at age 14 months. At age 8 years she was wheelchair-bound, and at age 19 years she had severe dementia.

Leukodystrophy, brain calcifications, and parenchymal cysts as a particular disorder was first described in 1996.1,2 Clinical manifestations include dementia, ataxia, and pyramidal and extrapyramidal findings. Imaging is important in the diagnosis of leukoencephalopathy with cerebral calcifications and cysts, since the combination of these findings is unusual. Gradient echo imaging revealed the extent of the abnormalities not seen by conventional MRI and CT (figure, A, B).

1. Labrune P, Lacroix C, Goutieres F, et al. Extensive brain calcifications, leukodystrophy, and formation of parenchymal cysts: a new progressive disorder due to diffuse cerebral microangiopathy. Neurology 1996;46: $1297-1301$.

2. Nagae-Poetscher LM, Bibat G, Philippart M, et al. Leukoencephalopathy, cerebral calcifications, and cysts: new observations. Neurology 2004; 62:1206-1209. 


\section{Neurology}

\section{Leukoencephalopathy with cerebral calcifications and cysts}

Christiana Brenner, Maria C. Del Negro, Eliana M.V. Borigato, et al.

Neurology 2006;66;E32

DOI 10.1212/01.wnl.0000204297.44936.27

\section{This information is current as of May 8, 2006}

\section{Updated Information \&} Services

References

\section{Subspecialty Collections}

Permissions \& Licensing

Reprints including high resolution figures, can be found at: http://n.neurology.org/content/66/9/E32.full

This article cites 2 articles, 2 of which you can access for free at: http://n.neurology.org/content/66/9/E32.full\#ref-list-1

This article, along with others on similar topics, appears in the following collection(s):

MRI

http://n.neurology.org/cgi/collection/mri

Information about reproducing this article in parts (figures,tables) or in its entirety can be found online at:

http://www.neurology.org/about/about_the_journal\#permissions

Information about ordering reprints can be found online:

http://n.neurology.org/subscribers/advertise

Neurology ${ }^{\circledR}$ is the official journal of the American Academy of Neurology. Published continuously since 1951, it is now a weekly with 48 issues per year. Copyright . All rights reserved. Print ISSN: 0028-3878. Online ISSN: 1526-632X.

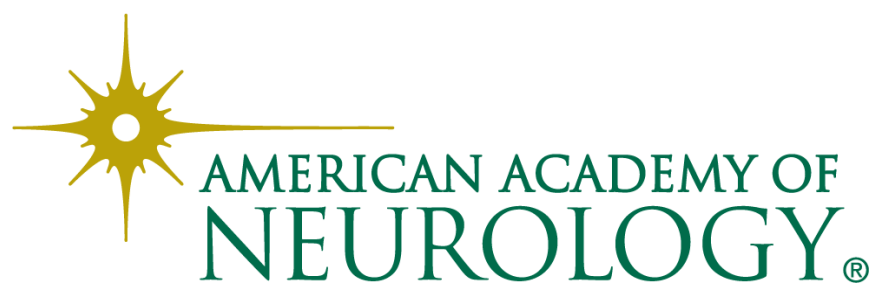

